\title{
Pengaruh Model Pembelajaran Problem Solving Fisika terhadap Kemampuan Penguasaan Konsep dan Kemampuan Pemecahan Masalah Siswa Kelas X MIPA SMAN 4 Kota Bengkulu
}

\author{
Mahilda Wiwit Handayani, Eko Swistoro, Eko Risdianto \\ Program Studi S1 Pendidikan Fisika, Jurusan Pendidikan MIPA \\ Fakultas Keguruan dan Ilmu Pendidikan, Universitas Bengkulu \\ Jalan W.R. Supratman, Kandang Limun, Bengkulu 38123 \\ E-mail : mahilda27@gmail.com
}

\begin{abstract}
ABSTRAK
Penelitian ini bertujuan untuk mengetahui pengaruh model pembelajaran Problem Solving Fisika terhadap kemampuan penguasaan konsep dan kemampuan pemecahan masalah siswa kelas X MIPA pada konsep momentum dan impuls. Penelitian ini menggunakan dua desain yaitu nonequivalent control group dan one group pretest-posttest. Sampel penelitian diambil menggunakan teknik purposive sampling sehingga diperoleh kelas X MIPA 1 sebagai kelas eksperimen dan kelas X MIPA 3 sebagai kelas kontrol. Instrumen yang digunakan berupa tes kemampuan penguasaan konsep (TKPK) dan tes kemampuan pemecahan masalah (TKPM). Berdasarkan analisis data menggunakan uji-T dua sampel independen diperoleh rata-rata posttest kedua kelas berbeda secara signifikan dengan nilai $t_{\text {hitung }}>t_{\text {tabel }}(2,03>2,00)$ dengan effect size sebesar 0,52, sehingga dapat disimpulkan bahwa terdapat pengaruh model Problem Solving Fisika terhadap kemampuan penguasaan konsep siswa dengan kategori sedang. Pada penelitian ini pengaruh model Problem Solving Fisika terhadap kemampuan pemecahan masalah diketahui dengan adanya selisih antara skor ratarata posttest dan skor rata-rata pretest siswa kelas eksperimen $\left(\mathrm{O}_{2}-\mathrm{O}_{1}\right)$ yaitu 38,04 dengan effect size sebesar 2,89, sehingga besar pengaruh model Problem Solving Fisika terhadap kemampuan pemecahan masalah fisika dikategorikan tinggi.
\end{abstract}

Kata kunci: Model Problem Solving Fisika, Kemampuan Penguasaan Konsep, Kemampuan Pemecahan Masalah

\begin{abstract}
This research was aimed to explain the effect of Physics Problem Solving model toward the ability of conceptmastery and problem solving ability of class X MIPA students in learning the concept of momentum and impulse. This research used two designs that are nonequivalent control group and one group pretestposttest. The sample was taken according to purposive sampling technique which decided class X MIPA 1 as the experimental class and class X MIPA 3 as the control class. The instrument used in this research were concept mastery skills test (TKPK) and problem solving test (TKPM). Based on the data analysis using Ttest two independent samples, the results obtained the average posttest of the two classes differed significantly scored $t_{\text {count }}>t_{\text {table }}(2,03>2,00)$ with the effect size of 0,52 , in conclusion there was the effect of Physics Problem Solving model toward the students concept mastery ability in medium category. In this research, the effect of Physics Problem Solving model toward problem solving ability was known by the difference between posttest average score and average score of pretest of experiment class student (O2 - O1) scored 38,04 with effect size about 2,89, so the effect of Physics Problem Solving model toward problem solving ability categorized high.
\end{abstract}

Keywords: Physics Problem Solving Model, Ability Mastery Concept, Problem Solving Ability

\section{PENDAHULUAN}

Pengembangan kurikulum 2013 didasarkan pada kompetensi dalam konteks pendidikan abad ke-21. Proses pembelajaran dalam kurikulum 2013 diarahkan agar dapat membekali siswa dengan empat ragam pengetahuan mulai dari pengetahuan yang bersifat faktual, konseptual, prosedural, dan metakognitif untuk mencapai standar kompetensi lulusan. Melalui empat jenis pengetahuan tersebut diharapkan siswa akan mampu menjadi seseorang yang dapat berpikir kritis, kreatif dan inovatif. Menurut Trilling \& Fadel (2009), kompetensi utama yang harus dimiliki dalam konteks pendidikan 
abad ke-21 berkenaan dengan kemampuan berpikir kreatif dan kemampuan pemecahan masalah, kemampuan berkomunikasi dan berkolaborasi, serta kemampuan untuk berkreativitas dan berinovasi $^{[1]}$.

Menurut Redish tujuan pembelajaran fisika baik ditingkat sekolah menengah maupun tingkat universitas adalah meningkatkan penguasaan konsep dan kemampuan pemecahan masalah. Dalam proses pembelajaran kemampuan pemecahan masalah dapat dikembangkan melalui model pembelajaran berbasis masalah. Salah satu model pembelajaran berbasis masalah yang dapat digunakan adalah model pembelajaran Problem Solving Fisika (PSF). Model PSF merupakan suatu model yang mengkolaborasikan antara problem solving dan pemahaman konsep fisika. Model pembelajaran Problem Solving Fisika terdiri atas lima langkah pembelajaran, yaitu: (1) memahami masalah, (2) menampilkan masalah secara fisika, (3) merencanakan pemecahan masalah (4) menjalankan rencana, (5) mengevaluasi jawaban dan perluasan. Tahapan di dalam model PSF sangat mendukung untuk pencapaian kemampuan pemecahan masalah serta penguasaan konsep yang merupakan tujuan utama dari suatu pembelajaran. Dalam menggunakan model PSF maka penguasaan konsep fisika adalah sebagai bekal untuk pemecahan masalah ${ }^{[2]}$.

Karakteristik pengetahuan fisika yang saling berhubungan antara konsep fisika yang satu dengan yang lain menjadi salah satu permasalahan bagi siswa dalam menguasai konsep-konsep fisika, misalnya pada materi momentum dan impuls. Berdasarkan hasil penelitian Lawson dan McDermott menunjukkan bahwa siswa melakukan kesalahan dalam memahami teori momentum dan impuls, misalnya mengaitkan hubungan antara konsep momentum dan konsep impuls dalam penyelesaian soal. Penelitian lain yang dilakukan oleh Close dan Heron melaporkan bahwa siswa cenderung meninjau hukum kekekalan momentum sebagai hukum kekekalan besaran skalar, bukan sebagai besaran vektor ${ }^{[3]}$.

Berdasarkan hasil wawancara di SMAN 4 Kota Bengkulu pada 12 januari 2018, dalam proses pembelajaran guru fisika kelas X MIPA menggunakan metode diskusi, tanya jawab dan eksperimen. Guru fisika di SMAN 4 Kota Bengkulu juga telah menerapkan beberapa model pembelajaran tetapi model pembelajaran yang digunakan belum secara maksimal mengembangkan kemampuan siswa dalam menguasai konsep-konsep fisika dan kemampuan pemecahan masalah fisika. Hasil belajar siswa kelas X MIPA pada ujian semester menunjukkan bahwa hanya $46 \%$ siswa yang mencapai batas ketuntasan (KKM). Hal ini berarti bahwa penguasaan konsep fisika yang dimiliki siswa masih rendah sehingga akan berdampak terhadap kemampuan siswa dalam memecahkan suatu permasalahan fisika.

Dalam proses pembelajaran, SMA Negeri 04 Kota Bengkulu sudah menerapkan kurikulum 2013. Pengembangan kurikulum 2013 ini didasarkan pada kompetensi dalam konteks pendidikan abad ke-21. Salah satu kompetensi utama yang harus dimiliki dalam konteks pendidikan abad ke-21 yaitu kemampuan pemecahan masalah. Oleh karena itu, model pembelajaran Problem Solving Fisika dapat dijadikan sebagai alternatif dalam mengembangkan kemampuan penguasaan konsep dan kemampuan pemecahan masalah fisika.

Hasil penelitian yang telah dilakukan Warimun (2012) menyatakan bahwa model pembelajaran Problem Solving Fisika (PSF) dapat meningkatkan penguasaan konsep fisika dalam topik optika dengan $\mathrm{N}$-gain sebesar $40,7 \%$ dan kemampuan problem solving siswa dalam optika geometri dengan rata-rata $\mathrm{N}$-gain sebesar $81,1 \%{ }^{[4]}$. Selanjutnya, penelitian yang dilakukan (Warimun, 2017) juga menunjukkan bahwa terdapat peningkatan kemampuan penguasaan konsep dan kemampuan problem solving mahasiswa pada materi kesetimbangan benda tegar setelah diajarkan dengan menggunakan model Problem Solving Fisika (PSF). Dalam (Warimun, 2017) pembelajaran dengan model PSF mempunyai beberapa kelebihan sebagai berikut: 1) langkahlangkah pemecahan masalahnya dapat membantu mempercepat siswa dalam memahami masalah dan menyusun persamaan matematis yang dibutuhkan, 2) dapat meningkatkan kesadaran siswa akan pengetahuan yang dipelajarinya, 3) dapat meningkatkan kemampuan pemecahan masalah, dan 4) dapat meningkatkan hasil belajar siswa. Tidak hanya itu, hasil penelitian yang telah dilakukan (Sijabat, 2013) juga menunjukkan adanya pengaruh model Problem Solving terhadap hasil belajar fisika siswa SMA ${ }^{[5]}$. 
Berdasarkan latar belakang masalah tersebut, penelitian ini memusatkan perhatian untuk menjawab rumusan masalah penelitian sebagai berikut: 1) Apakah terdapat pengaruh model pembelajaran Problem Solving Fisika terhadap kemampuan penguasaan konsep siswa kelas X MIPA di SMAN 4 Kota Bengkulu?, 2) Apakah terdapat pengaruh model pembelajaran Problem Solving Fisika terhadap kemampuan pemecahan masalah fisika siswa kelas X MIPA di SMAN 4 Kota Bengkulu?. Kemampuan penguasaan konsep dalam penelitian ini meliputi domain kognitif Anderson yaitu $\mathrm{C} 2 \mathrm{~F}$ (memahami pada pengetahuan faktual), $\mathrm{C} 2 \mathrm{~K}$ (memahami pada pengetahuan konseptual), C3K (menerapkan pada pengetahuan konseptual), dan $\mathrm{C} 4 \mathrm{~K}$ (menganalisis pada pengetahuan konseptual). Kriteria kemampuan pemecahan masalah fisika yang digunakan dalam penelitian ini merupakan kemampuan problem solving yang dikembangkan oleh Warimun yaitu: Kemampuan Memahami Masalah Secara Umum (KMMU), Kemampuan Memahami Masalah Secara Fisika (KMMF), Kemampuan Membuat Rencana Pemecahan Masalah (KMRP), Kemampuan Menjalankan Rencana (KMR), dan Kemampuan Menghitung (KM). Penelitian ini dilakukan pada materi momentum dan impuls.

\section{METODE PENELITIAN}

Penelitian ini menggunakan dua desain yaitu quasi experimental design (eksperimen semu) untuk melihat pengaruh model pembelajaran PSF terhadap kemampuan penguasaan konsep siswa dan pre-experimental designs untuk melihat pengaruh model PSF terhadap kemampuan pemecahan masalah. Bentuk desain quasi experimental dalam penelitian ini adalah nonequivalent control group. Bentuk desain nonequivalent control group dapat dilihat pada tabel di bawah ini:

Tabel 1. Desain Nonequivalent Control Group

\begin{tabular}{|c|c|c|c|}
\hline Kelas & Pretest & Perlakuan & Posttest \\
\hline Eksperimen & $\mathrm{O}_{1}$ & $\mathrm{X}$ & $\mathrm{O}_{2}$ \\
\hline Kontrol & $\mathrm{O}_{3}$ & & $\mathrm{O}_{4}$ \\
\hline
\end{tabular}

Pada penelitian ini, kelas eksperimen mengikuti pembelajaran menggunakan model Problem Solving Fisika sedangkan kelas kontrol menggunakan pembelajaran konvensional. Dalam penelitian ini juga digunakan desain one-group pretest-posttest yang merupakan bentuk pre-experimental designs., sebab tes kemampuan pemecahan masalah hanya dilakukan di kelas eksperimen yang dalam proses pembelajarannya menggunakan model pembelajaran Problem Solving Fisika ${ }^{[6]}$. Menurut (Sugiyono, 2012) bentuk desain one-group pretest-posttest dapat dilihat pada tabel 2.

Tabel 2. Desain One-Group Pretest-Posttest

\begin{tabular}{|c|c|c|}
\hline Pretest & Perlakuan & Posttest \\
\hline $\mathrm{O}_{1}$ & $\mathrm{X}$ & $\mathrm{O}_{2}$ \\
\hline
\end{tabular}

Populasi dalam penelitian ini adalah seluruh siswa kelas X MIPA di SMA Negeri 04 Kota Bengkulu semester genap tahun ajaran 2017/2018 yang berjumlah empat kelas. Pengambilan sampel dalam penelitian ini menggunakan teknik purposive sampling. Beberapa hal yang menjadi pertimbangan dalam pengambilan sampel yaitu berdasarkan jumlah jam tiap satu kali pertemuan (3 jam pelajaran) dan tingkat kemampuan rata-rata kedua kelas sama. Selain itu, syarat kedua kelas yang menjadi sampel harus normal dan homogen. Berdasarkan pertimbangan dan syarat tersebut, diperoleh dua kelas yang menjadi sampel yaitu kelas X MIPA 1 sebagai kelas eksperimen dan X MIPA 3 sebagai kelas kontrol.

Pada penelitian ini instrumen yang digunakan dalam pengumpulan data berupa instrumen tes yang terdiri dari tes kemampuan penguasaan konsep (TKPK) dan tes kemampuaan pemecahan masalah (TKPM). Tes kemampuan penguasaan konsep (TKPK) dibuat dalam bentuk soal uraian yang terdiri atas 5 soal untuk setiap pertemuan. Taraf penguasaan konsep siswa dapat dikategorikan berdasarkan hasil tes seperti yang terlihat pada tabel 3 .

Tabel 3. Kriteria Taraf Penguasaan Konsep

\begin{tabular}{|c|c|}
\hline Taraf Nilai Rata-Rata & Klasifikasi Nilai \\
\hline $91-100$ & Sangat Baik \\
\hline $83-90$ & Baik \\
\hline
\end{tabular}




\begin{tabular}{|c|c|}
\hline Taraf Nilai Rata-Rata & Klasifikasi Nilai \\
\hline $75-82$ & Cukup Baik \\
\hline$<75$ & Kurang Baik \\
\hline
\end{tabular}

Tes kemampuan pemecahan masalah (TKPM) dibuat dalam bentuk soal uraian sebanyak 3 soal untuk keseluruhan pertemuan. TKPM dibuat dengan menggunakan lembar jawaban dengan langkah-langkah pemecahan masalah fisika. Tes kemampuan pemecahan masalah yang diukur dalam penelitian ini merupakan kemampuan pemecahan masalah yang dikembangkan oleh (Warimun, 2017), antara lain Kemampuan Memahami Masalah Secara Umum (KMMU), Kemampuan Memahami Masalah Secara Fisika (KMMF), Kemampuan Membuat Rencana Pemecahan Masalah (KMRP), Kemampuan Menjalankan Rencana (KMR), dan Kemampuan Menghitung (KM). Kriteria kemampuan pemecahan masalah fisika ini dapat dikategorikan berdasarkan skor rata-rata tes seperti yang terlihat pada tabel 4.

Tabel 4. Kriteria Kemampuan Pemecahan Masalah Fisika

\begin{tabular}{|c|c|}
\hline Taraf Skor Rata-Rata & Klasifikasi Skor \\
\hline $80<$ mean $\leq 100$ & Baik \\
\hline $60<$ mean $\leq 80$ & Cukup \\
\hline $40<$ mean $\leq 60$ & Kurang \\
\hline $20<$ mean $\leq 40$ & Sangat Kurang \\
\hline
\end{tabular}

Setiap aspek kemampuan pemecahan masalah memiliki skor tersendiri. Adapun persamaan yang digunakan untuk memperoleh skor akhir dari setiap aspek kemampuan pemecahan masalah dapat dilihat pada persamaan (1).

$$
S_{A}=\frac{Q_{i} \times 100}{E_{i}}, i=1,2,3,4,5
$$

Persamaan di atas menunjukkan bahwa $S_{A}$ adalah skor akhir setiap aspek kemampuan pemecahan masalah, $Q_{i}$ adalah total skor siswa untuk setiap aspek $\mathrm{KPM}, \mathrm{E}_{\mathrm{i}}$ adalah total skor maksimal untuk setiap aspek KPM $\left(E_{i}=15\right)$, dan $i$ merupakan indeks untuk setiap aspek, misalnya $i$ = 1 menunjukan aspek kemampuan memahami masalah secara umum (KMMU). Skor akhir yang diperoleh dari persamaan tersebut dapat dikategorikan berdasarkan tingkat kemampuan siswa seperti yang terlihat pada tabel $5^{[7]}$.

Tabel 5. Kategori Tingkat Kemampuan Siswa

\begin{tabular}{|c|c|}
\hline Taraf Skor Akhir & Tingkat Kemampuan Siswa \\
\hline $76-100$ & Tinggi \\
\hline $61-75$ & Sedang \\
\hline$\leq 60$ & Rendah \\
\hline
\end{tabular}

Pada penelitian ini analisis data dilakukan terhadap skor pretest dan skor posttest yang diperoleh siswa. Data tersebut dioalah dan dianalisis menggunakan analisis deskriptif dan analisis inferensial. Dalam penelitian ini analisis deskriptif digunakan untuk mendeskripsikan nilai rata-rata (mean) dan standar deviasi untuk pretest dan posttest, serta analisis pengaruh model Problem Solving Fisika terhadap kemampuan pemecahan masalah dan analisis besar pengaruh (effect size) menggunakan rumus Cohend. Menurut Olejnik dan Algina effect size merupakan ukuran mengenai besarnya efek suatu variabel pada variabel lain ${ }^{[8]}$. Besar pengaruh model pembelajaran Problem Solving Fisika terhadap kemampuan penguasaan konsep dapat ditentukan menggunakan persamaan (2).

$$
d=\frac{\bar{x}_{1}-\bar{x}_{2}}{S_{\text {pooled }}}
$$

keterangan: $\mathrm{d}$ adalah effect size, $\bar{x}_{1}$ adalah skor rata-rata posttest kelas eksperimen, $\bar{x}_{2}$ adalah skor rata-rata posttest kelas kontrol, dan $S_{\text {pooled }}$ adalah standar deviasi gabungan. Standar deviasi gabungan ditentukan menggunakan persamaan (3). 


$$
S_{\text {pooled }}=\sqrt{\frac{\left(n_{1}-1\right) S_{1}^{2}+\left(n_{2}-1\right) S_{2}^{2}}{n_{1}+n_{2}-2}}
$$

Besar pengaruh model pembelajaran Problem Solving Fisika terhadap kemampuan pemecahan masalah dapat diketahui dari keadaan sebelum dan setelah diberi perlakuan. Menurut Cohen's dan Becker untuk mengetahui besar pengaruh setelah diberikan perlakuan dibutuhkan skor rata-rata sebelum diberi perlakuan $\left(\bar{x}_{p r e}\right)$ dan skor rata-rata setelah diberi perlakuan $\left(\bar{x}_{\text {post }}\right)$, serta standar deviasi sebelum diberi perlakuan $\left(S_{p r e}\right)$ dan standar deviasi setelah diberi perlakuan $\left(S_{\text {post }}\right)$, sehingga persamaan effect size dirumuskan sebagai berikut ${ }^{[9]}$ :

$$
\begin{gathered}
d=\frac{\left(\bar{x}_{\text {post }}\right)-\left(\bar{x}_{\text {pre }}\right)}{S_{\text {pooled }}} \\
S_{\text {pooled }}=\sqrt{\frac{S_{p r e}^{2}+S_{p o s t}^{2}}{2}}
\end{gathered}
$$

Hasil perhitungan effect size dapat diinterpretasikan dengan menggunakan klasifikasi menurut Cohen's seperti yang terlihat pada tabel $6^{[10]}$.

Tabel 6. Klasifikasi Effect Size

\begin{tabular}{|c|c|}
\hline Besar $\mathrm{d}$ & Interpretasi \\
\hline $\mathrm{d} \geq 0,8$ & Tinggi \\
\hline $0,5 \leq \mathrm{d}<0,8$ & Sedang \\
\hline $\mathrm{d}<0,5$ & Rendah \\
\hline
\end{tabular}

Analisis inferensial yang digunakan yaitu analisis parametrik atau analisis uji-T. Analisis uji $\mathrm{t}$ dapat dilakukan jika data berdistribusi normal dan homogen. Data yang digunakan dalam penelitian ini diuji normalistas menggunakan rumus chi kuadrat dan uji homogenitas menggunakan uji Harley untuk mengetahui data tersebut berdistribusi normal dan homogen.

Pada penelitian ini jumlah anggota sampel kelas eksperimen dan kelas kontrol berbeda, maka uji t yang akan digunakan akan dilihat berdasarkan homogenitas kedua sampel. Apabila kelas eksperimen dan kelas sampel homogen maka analisis uji t yang digunakan merupakan t test polled varian, dengan persamaan (6).

$$
t=\frac{\overline{X_{1}}-\overline{X_{2}}}{\sqrt{\frac{\left(n_{1}-1\right) s_{1}^{2}+\left(n_{2}-1\right) s_{2}^{2}}{n_{1}+n_{2}-2}\left(\frac{1}{n_{1}}+\frac{1}{n_{2}}\right)}}
$$

keterangan: $\mathrm{t}$ adalah nilai $\mathrm{t}$ hitung, $\overline{X_{1}}$ adalah nilai rata-rata kelompok $1, \overline{X_{2}}$ adalah nilai rata-rata kelompok $2, n_{1}$ adalah jumlah sampel kelompok $1, n_{2}$ adalah jumlah sampel kelompok $2, s_{1}^{2}$ adalah varian kelompok 1, dan $s_{2}^{2}$ adalah varian kelompok 2 (Sugiyono, 2012).

Jika harga $t_{\text {hitung }}>\mathrm{t}_{\text {tabel }}$ pada taraf signifikansi 0,05 dan derajat kebebasan $(d k)=n_{1}+n_{2}-$ 2, maka $\mathrm{H}_{\mathrm{a}}$ diterima sedangkan $\mathrm{H}_{0}$ ditolak. Jika harga $\mathrm{t}_{\text {hitung }}<\mathrm{t}_{\text {tabel }}$ maka $\mathrm{H}_{\mathrm{a}}$ ditolak sedangkan $\mathrm{H}_{0}$ diterima. Berdasarkan analisis data yang diperoleh dapat disimpulkan bahwa hipotesis yang diajukan dalam penelitian ini apakah diterima atau ditolak.

\section{HASIL DAN PEMBAHASAN}

\subsection{Pengaruh Model Pembelajaran Problem Solving Fisika Terhadap Kemampuan Penguasaan Konsep Siswa}

Hasil tes kemampuan penguasaan konsep (TKPK) yang merupakan data dalam penelitian ini berupa hasil rata-rata pretest dan posttest siswa. Penelitian ini dilakukan dalam tiga pertemuan. Pada pertemuan pertama materi yang diajarkan yaitu momentum dan impuls serta hubungan antara 
keduanya, pertemuan kedua yaitu hukum kekekalan momentum, dan pertemuan ketiga yaitu tumbukan. Kemampuan penguasaan konsep siswa terhadap konsep momentum dan impuls diukur dengan tes kemampuan penguasaan konsep (TKPK) dalam bentuk soal essai sebanyak 5 soal setiap pertemuan. Data pretest digunakan untuk mengetahui apakah pengetahuan awal siswa kelas eksperimen dan kontrol sama sebelum diberi perlakuan. Pada akhir pembelajaran, siswa diberikan posttest untuk mengetahui adanya perbedaan kemampuan penguasaan konsep siswa setelah diberi perlakuan. Adapun hasil data rata-rata pretest dan posttest kelas eksperimen dan kontrol dapat dilihat pada tabel 7 .

Tabel 7. Data Skor Rata-Rata TKPK

\begin{tabular}{|c|c|c|}
\hline Kelas & Pretest & Posttest \\
\hline Eksperimen & 37,89 & 78,83 \\
\hline Kontrol & 36,63 & 74,09 \\
\hline
\end{tabular}

Pada tabel di atas terlihat bahwa skor rata-rata posttest kelas eksperimen sebesar 78,83 sehingga dapat dikatakan penguasaan konsep yang dimiliki siswa dikategorikan cukup baik, sedangkan skor rata-rata posttest kelas kontrol sebesar 74,09 maka penguasaan konsep siswa dikategorikan kurang baik. Berdasarkan uji perbedaan rata-rata posttest kedua sampel (uji t) terlihat bahwa $t_{\text {hitung }}>t_{\text {tabel }}$ pada taraf signifikansi 5\% dengan $\mathrm{dk}=60$, sehingga dapat disimpulkan bahwa rata-rata posttest kedua kelas berbeda secara signifikan. Hal ini membuktikan bahwa terdapat pengaruh model pembelajaran Problem Solving Fisika terhadap kemampuan penguasaan konsep fisika. Berdasarkan hasil perhitungan effect size menggunakan rumusan Cohen's diperoleh besarnya pengaruh model pembelajaran Problem Solving Fisika terhadap kemampuan penguasaan konsep fisika sebesar 0,52, sehingga besar pengaruh model Problem Solving Fisika dapat dikategorikan sedang.

Model pembelajaran Problem Solving Fisika (PSF) dapat meningkatkan penguasaan konsep fisika dikarenakan dalam proses pembelajaran siswa terlibat dalam kelompok untuk mendisukusikan suatu masalah. Siswa yang berada dalam suatu kelompok dapat saling membantu dalam menyelesaikan masalah dan membangun konsep yang akan digunakan dalam suatu permasalahan fisika. Sebelum melakukan diskusi kelompok siswa diberikan beberapa pertanyaan konstruksi yang dapat memberi peluang kepada siswa untuk membangun pengetahuannya, kemudian guru akan memberikan demonstrasi terkait dengan materi yang diajarkan dan selanjutnya guru akan memberikan siswa suatu masalah yang dituangkan dalam lembar kerja problem solving. Senada dengan hal itu (Warimun, 2017) menyatakan bahwa untuk meningkatkan efektivitas model Problem Solving Fisika dalam meningkatkan penguasaan konsep fisika, maka pembelajaran dilakukan dengan diskusi kelompok menggunakan LKS (lembar kerja problem solving). Hal ini juga telah dibuktikan oleh (Sijabat, 2013) dalam penelitiannya yang menunjukkan bahwa pembelajaran yang menggunakan model Problem Solving diperlukan bahan ajar berupa LKS yang dirancang berdasarkan permasalahan kontekstual. Dalam penelitiannya, (Sijabat, 2013) mengungkapkan bahwa penguasaan konsep fisika siswa yang diajarkan menggunakan model pembelajaran Problem Solving lebih baik dibandingkan dengan siswa yang diajarkan menggunakan pembelajaran konvensional.

\subsection{Pengaruh Model Pembelajaran Problem Solving Fisika Terhadap Kemampuan Pemecahan Masalah Fisika}

Kemampuan pemecahan masalah fisika dalam penelitian ini dilakukan di kelas eksperimen. Siswa di kelas eksperimen diajarkan menggunakan model pembelajaran Problem Solving Fisika untuk mengetahui kemampuan pemecahan masalah fisika. Siswa diberikan tes berupa tes kemampuan pembecahan masalah (TKPM) dalam bentuk soal essai dengan menggunakan lembar jawaban khusus. Tes ini terdiri dari 1 soal untuk setiap pertemuan. Berdasarkan hasil penelitian diperoleh data skor rata-rata pretest dan posttest kemampuan pemecahan masalah dapat dilihat dari grafik pada gambar 1 . 


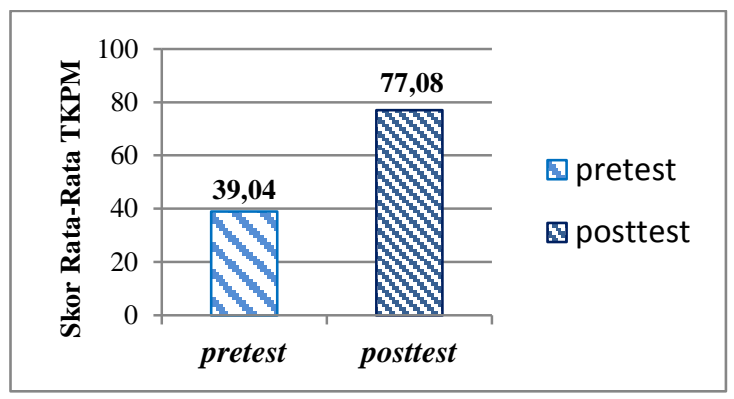

Gambar 1. Grafik Skor Rata-Rata Tes Kemampuan Pemecahan Masalah

Berdasarkan grafik pada gambar 1 terlihat bahwa skor rata-rata pretest TKPM sebesar 39,04, sedangkan skor rata-rata posttest sebesar 77,08. Hal ini menunjukan bahwa setelah diberi perlakuan berupa model pembelajaran Problem Solving Fisika, siswa mengalami peningkatan kemampuan pemecahan masalah fisika. Berdasarkan kriteria kemampuan pemecahan masalah fisika pada tabel 2.4 dapat dikatakan bahwa kemampuan pemecahan masalah yang dimiliki siswa setelah mengikuti pembelajaran dikategorikan cukup. Menurut (Sugiyono, 2012), pengaruh model pembelajaran Problem Solving Fisika ini dapat diketahui dengan cara mengurangi skor rata-rata posttest dengan skor rata-rata pretest $\left(\mathrm{O}_{2}-\mathrm{O}_{1}\right)$. Selisih yang diperoleh dari hasil pengurangan tersebut sebesar 38,04 . Selisih antara skor rata-rata posttest dan skor rata-rata pretest menunjukkan adanya pengaruh model pembelajaran Problem Solving Fisika terhadap kemampuan pemecahan masalah fisika. Besarnya pengaruh model pembelajaran Problem Solving Fisika terhadap kemampuan pemecahan masalah fisika dapat diperoleh dari hasil perhitungan menggunakan persamaan Cohen's. Berdasarkan hasil perhitungan effect size menggunakan rumusan Cohen's diketahui besarnya pengaruh model pembelajaran Problem Solving Fisika terhadap kemampuan pemecahan masalah fisika sebesar 2,89, sehingga besar pengaruh model Problem Solving Fisika dapat dikategorikan tinggi.

Kemampuan pemecahan masalah dalam penilitian ini terdiri dari lima aspek kemampuan. Skor posttest yang diperoleh dari setiap aspek kemampuan pemecahan masalah dapat dikategorikan menjadi tingkat kemampuan tinggi, sedang, dan rendah. Adapun persentase banyaknya siswa berdasarkan tingkat kemampuan siswa untuk setiap aspek kemampuan pemecahan masalah dapat dilihat dalam grafik pada gambar 2.

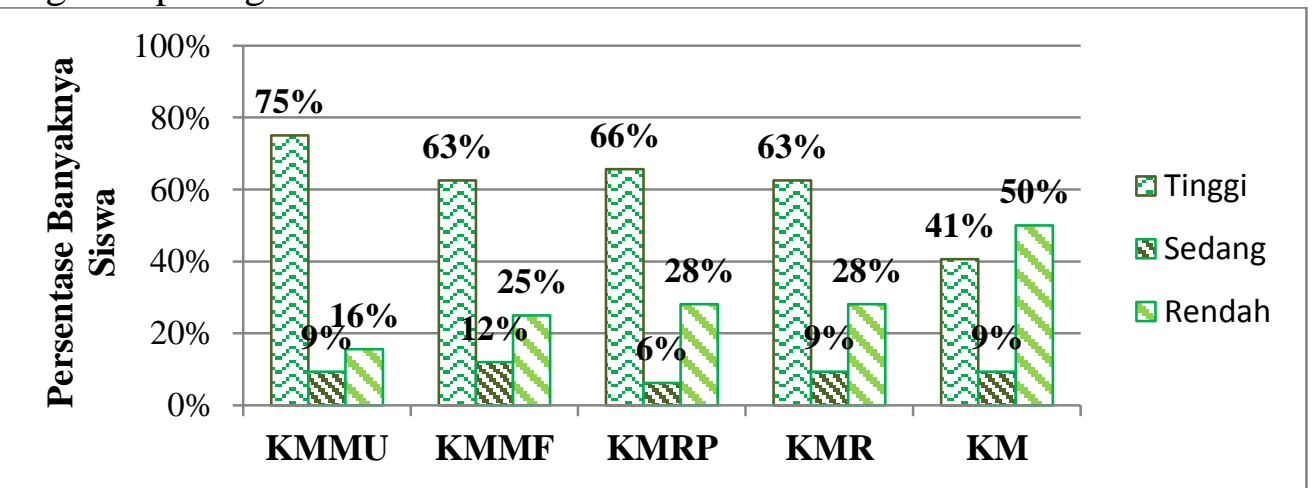

Gambar 2. Grafik Persentase Banyaknya Siswa Berdasarkan Tingkat Kemampuan Siswa untuk

Setiap Aspek Kemampuan Pemecahan Masalah

Grafik di atas menunjukkan bahwa pada aspek kemampuan memahami masalah secara umum (KMMU), persentase tertinggi diperoleh dari siswa dalam tingkat kemampuan tinggi yaitu sebesar 75\%. Hal ini menunjukkan bahwa setelah mengikuti pembelajaran, kemampuan siswa dalam memahami masalah secara kualitatif sangat baik. Pada aspek kemampuan memahami masalah secara fisika (KMMF), siswa dikategorikan memiliki tingkat kemampuan yang tinggi dengan persentase sebesar 63\%. Hal tersebut menunjukkan bahwa siswa dapat memahami suatu permasalahan secara fisika (kuantitatif). Pada aspek kemampuan membuat rencana pemecahan masalah (KMRP), persentase terbesar diperoleh dari siswa dalam tingkat kemampuan yang tinggi yaitu sebesar $66 \%$. Hal ini menunjukkan bahwa siswa dapat membuat rencana dalam memecahkan 
suatu permasalahan, seperti menentukan konsep fisika yang digunakan. Pada aspek kemampuan menjalankan rencana (KMR), siswa dikategorikan memiliki kemampuan tinggi dengan persentase sebesar $63 \%$. Hal ini menunjukkan bahwa siswa dapat menjalankan rencana penyelesaian masalah sesuai dengan konsep fisika yang telah ditentukan. Pada aspek kemampuan menghitung (KM), persentase terbesar diperoleh dari siswa dalam tingkat kemampuan yang rendah yaitu sebesar $50 \%$. Hal ini menunjukkan bahwa dalam menyelesaikan permasalahan fisika secara menyeluruh, siswa masih mengalami kesulitan dalam menggunakan aturan matematis sehingga terjadi kesalahan dalam perhitungan. Secara keseluruhan dapat dikatakan bahwa setelah mengikuti pembelajaran menggunkan model Problem Solving Fisika, siswa memiliki tingkat kemampuan pemecahan masalah yang tinggi. Hasil penelitian ini juga diperkuat oleh hasil penelitian (Warimun, 2017) yang menunjukkan bahwa penggunaan model Problem Solving Fisika dapat meningkatkan kemampuan problem solving dengan $\mathrm{N}$-gain sebesar 0,51 . Hasil penelitian Warimun ini juga konsiten dengan hasil-hasil penelitian sebelumnya (Warimun, 2012; Warimun, 2014). Jadi dapat disimpulkan bahwa hasil penelitian ini menunjukkan kesesuaian dengan hasil-hasil penelitian yang telah dilakukan Warimun, sehingga memperkuat bahwa adanya pengaruh model pembelajaran Problem Solving Fisika terhadap kemampuan pemecahan masalah fisika.

\section{KESIMPULAN DAN SARAN \\ 4.1 Kesimpulan}

Berdasarkan analisis data dan pembahasan, kesimpulan dari penelitian ini sebagai berikut: (1) Terdapat pengaruh penggunaan model pembelajaran Problem Solving Fisika terhadap kemampuan penguasaan konsep fisika pada konsep momentum dan impuls. Hal ini terlihat dari hasil uji t-test polled varian yang menunjukkan bahwa hasil $t_{\text {hitung }}>t_{\text {tabel }}(2,03>2,00)$, sehingga dapat disimpulkan bahwa rata-rata posttest kelas eksperimin dan kelas kontrol berbeda secara signifikan. Besar pengaruh model Problem Solving Fisika terhadap kemampuan penguasaan konsep sebesar 0.52 dengan kategori sedang, (2) Terdapat pengaruh penggunaan model pembelajaran Problem Solving Fisika terhadap kemampuan pemecahan masalah fisika pada konsep momentum dan impuls. Hal ini ditunjukkan dengan adanya selisih skor rata-rata posttest dengan skor rata-rata pretest $\left(\mathrm{O}_{2}-\mathrm{O}_{1}\right)$ sebesar 38,04. besar pengaruh model Problem Solving Fisika terhadap kemampuan pemecahan masalah sebesar 2,89 dengan kategori tinggi.

\subsection{Saran}

Berdasarkan hasil penelitian ini dapat disarankan: (1) Model pembelajarn PSF dapat dijadikan sebagai alternatif model pembelajaran yang dapat digunakan untuk meningkatkan penguasaan konsep dan kemampuan pemecahan masalah fisika, (2) Dalam menunjang penggunaan model pembelajarn Problem Solving Fisika dapat digunakan LKS disertai kegiatan praktikum sehingga dapat membantu siswa untuk memahami secara mendalam konsep dan pengetahuan fisika, (3) Perlu dilakukan penelitian lanjutan mengenai pengaruh model Problem Solving Fisika terhdap kemampuan penguasaan konsep pada dimensi pengetahuan prosedural dan metakognitif dan kemampuan pemecahan masalah pada dimensi proses kognitif mengevaluasi (C5) dan mencipta (C6), (4) Perlu dilakukan penelitian lanjutan pada materi fisika yang berbeda.

\section{DAFTAR PUSTAKA}

[1] Abidin, Y. (2016). Desain SIstem Pembelajaran Dalam Konteks Kurikulum 2013. Bandung: Refika Aditama.

[2] Warimun, E. S. (2017). Peningkatan Pemahaman Konsep Dan Keterampilan Problem Solving Mahasiswa Melalui Pembelajaran Model Problem Solving Pada Materi Kesetimbangan Benda Tegar. Seminar Nasional Magister Pendidikan Dasar (hal. 113-119). Bengkulu: FKIP Universitas Bengkulu.

[3] Sutopo. (2016). Conceptual Problem Solving (CPS) untuk Meningkatkan Penguasaan Konsep Fisika Siswa SMA pada Materi Momentum Impuls. Pros. Semnas pendidikan IPA Pascasarjana UM. Vol. 1, hal. 70. Malang: Universitas Negeri Malang. 
[4] Warimun, E. S. (2012). Penerapan Model Pembelajaran Problem Solving Fisika Pada Materi Pembelajaran Topik Optika Pada Mahasiswa Pendidikan Fisika. Jurnal Exacta, Vol. X, No.2, 112.

[5] Sijabat, A. (2013). Pengaruh Model Pembelajaran Problem Solving Dan Pemahaman Konsep Terhadap Hasil Belajar Fisika Siswa. Jurnal Pendidikan Fisika, 88-91

[6] Sugiyono. (2012). Metode Penelitian Kuantitatif Kualitatif dan R\&D. Bandung: Alfabeta.

[7] Ninik,Hobri,\& Suharto. (2014). Analisis Kemampuan Pemecahan Masalah Untuk Setiap Tahap Model Polya Dari Siswa SMK Ibu Pakusari Jurusan Multi Media. Kadikma, Vol. 5, 64-65.

[8] Santoso, A. (2010). Studi Deskriptif Effect Size Penelitian Di Fakultas Psikologi Universitas Sanata Dharma. Jurnal Ilmiah Psikologi Universitas Santa Dharma, Vol. 14, No.1, hal. 34.

[9] Rajendra \& Kevin. (2012). A SAS Macro to Compute Effect Size (Cohen's ) and its Confidence Interval from Raw Survey Data. SESUG, Hal. 3.

[10] Asri,Andi,\& Ika. (2015). Ukuran Pengaruh Pendekatan Interactive Conceptual Instruction Pada Pembelajaran Fisika Untuk Meningkatkan Pemahaman Konsep Usaha dan Energi Siswa SMA. Prosiding Simposium Nasional Inovasi dan Pembelajaran Sains (hal. 263). Bandung: UPI. 